\section{The effects of post-pasture woody plant colonization on soil and aboveground litter carbon and nitrogen along a bioclimatic transect}

\author{
Tommaso La Mantia, Luciano Gristina, Ennio Rivaldo, Salvatore Pasta, \\ Agata Novara, Juliane Ruihl
}

We investigated the effects of woody plant colonization of abandoned pastures on soil and litter organic carbon $(C)$ stocks and nitrogen $(\mathrm{N})$ content along a bioclimatic transect in a semi-arid environment (Sicily, Italy). Soil samples were taken in three successional stages (grazed pasture, shrubland, forest) within each of three bioclimates (supramediterranean - "supra", mesomediterranean - "meso", thermomediterranean - "thermo"). Organic C and $\mathrm{N}$ in litter and soil $(0-10 \mathrm{~cm}$ and $10-30 \mathrm{~cm}$ depth) were determined, as well as soil bulk density. Especially at $0-10 \mathrm{~cm}$ depth, changes in $\mathrm{C}$ and $\mathrm{N}$ contents along successional stages differed among bioclimates. Soil organic carbon (SOC) stock decreased from pasture to shrubland and increased from shrubland to forest in "supra", increased from pasture to shrubland and then remained stable in "thermo", and was stable in "meso". Soil C/N ratio decreased with succession in "supra", showed no significant trend in "meso", and increased with succession in "thermo". Litter C stock increased with succession in "meso", increased from pasture to shrubland and decreased from shrubland to forest in "thermo", and increased from pasture to shrubland and then remained stable in "supra". Litter C/N ratio increased in "thermo" and "supra" from pasture to shrubland and from shrubland to forest, but did not change significantly with succession in "meso". The different trends in SOC among bioclimates may be caused by changes in the importance of litter input, litter decay rate and mineralization. Successional changes in "meso" and "supra" appeared to be most affected by litter quality, while those in "thermo" appeared to be strongly influenced by limited litter decay due to low soil moisture and high temperature.

Keywords: SOC Change, C/N Ratio, Secondary Succession, Mediterranean

\begin{abstract}
Introduction
After oceans, soils represent the largest carbon $(\mathrm{C})$ reservoir on Earth. To a depth of 1 $\mathrm{m}$, soils contain $1550 \mathrm{Gt}$ of organic $\mathrm{C}$ and $950 \mathrm{Gt}$ of inorganic C, more than the sum of $\mathrm{C}$ stored in terrestrial vegetation $(560 \mathrm{Gt})$ and the atmosphere $(760 \mathrm{Gt}$ - Lal 2004a, $2004 b)$. The size of the soil organic carbon (SOC) pool reflects $\mathrm{C}$ inputs of plant-derived organic matter residues and $\mathrm{C}$ losses resulting from mineralization (as carbon di-
\end{abstract}

oxide), leaching of dissolved organic $\mathrm{C}$, and erosion. Vegetation, precipitation, and temperature determine a steady state level of $\mathrm{C}$ content for each soil (Guo \& Gifford 2002, Paul et al. 2002, Dawson \& Smith 2007), but this equilibrium between input and output can be modified by land-use change. In the last decades, one of the most important types of land-use change, particularly in the midlatitudes of the northern hemisphere, has been the abandonment of agricultural lands

$\square$ Dipartimento Scienze Agrarie e Forestali, University of Palermo, v.le delle Scienze, Ed. 4, I-90128 Palermo (Italy)

@ Tommaso La Mantia (tommaso.lamantia@unipa.it)

Received: Oct 05, 2012 - Accepted: Mar 17, 2013

Citation: La Mantia T, Gristina L, Rivaldo E, Pasta S, Novara A, Rühl J, 2013. The effects of post-pasture woody plant colonization on soil and aboveground litter carbon and nitrogen along a bioclimatic transect. iForest 6: 238-246 [online 2013-06-13] URL:

http://www.sisef.it/ iforest/contents/?id=ifor0811-006

Communicated by: Giorgio Matteucci
(FAO 2012). In general, the abandonment of cultivated or grazed lands results in colonization by woody plants (secondary succession). The species composition of successional plant communities varies along with macro- and mesoclimate and other abiotic and biotic factors (West et al. 1981). In the Mediterranean area, the recent abandonment of marginal agricultural areas (pasture and/or arable land) has caused an increase in the area occupied by pre-forest and forest communities (Bonet 2004).

In the context of the Kyoto Protocol, research is needed to understand the process of $\mathrm{C}$ sequestration in soil. Areas subject to secondary succession are of particular interest because they might have great potential as $\mathrm{C}$ sinks (Alberti et al. 2011). Soil C dynamics after agricultural abandonment have been quantified in many studies (Knops \& Tilman 2000, Davis et al. 2003, Vuichard et al. 2008, Kuemmerle et al. 2011), and the spread of woody plants into grasslands/pastures/croplands is generally thought to increase the $\mathrm{C}$ stored in these ecosystems (Prévosto et al. 2006, La Mantia et al. 2007, Montané et al. 2007, Alberti et al. 2011). Some authors, however, have reported that secondary succession causes a reduction in soil C (Goodale \& Davidson 2002, Guo \& Gifford 2002, Jackson et al. 2002, Paul et al. 2002, Alberti et al. 2008). It follows that further studies are required on factors that determine whether SOC increases or decreases after agricultural abandonment. One of these factors may be climate (Jackson et al. 2002). In a study in Italy, for example, changes in SOC after agricultural abandonment were significantly related to annual rainfall (Alberti et al. 2011).

$\mathrm{C}$ and $\mathrm{N}$ dynamics in soils of abandoned fields are also likely to be affected by plant community composition. The main way the vegetation influences $\mathrm{C}$ and $\mathrm{N}$ input into soils is through litter deposition (Koukoura et al. 2003, Cortez et al. 2007, Foote \& Grogan 2010). Many factors including temperature, moisture, $\mathrm{pH}$, and other abiotic environmental conditions determine the quantity and quality of litter $\mathrm{C}$ and $\mathrm{N}$ inputs (Mayer 2008, Poll et al. 2008) and the composition and abundance of the decomposer community (Rutigliano et al. 2004, Aneja et al. 2005, Cortez et al. 2007, Liao \& Boutton 2008, Fioretto et al. 2009). All these factors change with time-since-abandonment because plant community composition and soil characteristics are in continuous transformation during succession (Luken 1990, GlennLewin et al. 1992).

Litter quality, often measured as $\mathrm{C} / \mathrm{N}$ ratio or lignin content, is frequently used to indicate the transformability of litter to humified organic matter. Regarding secondary succession, Montané et al. (2010) found that de- 


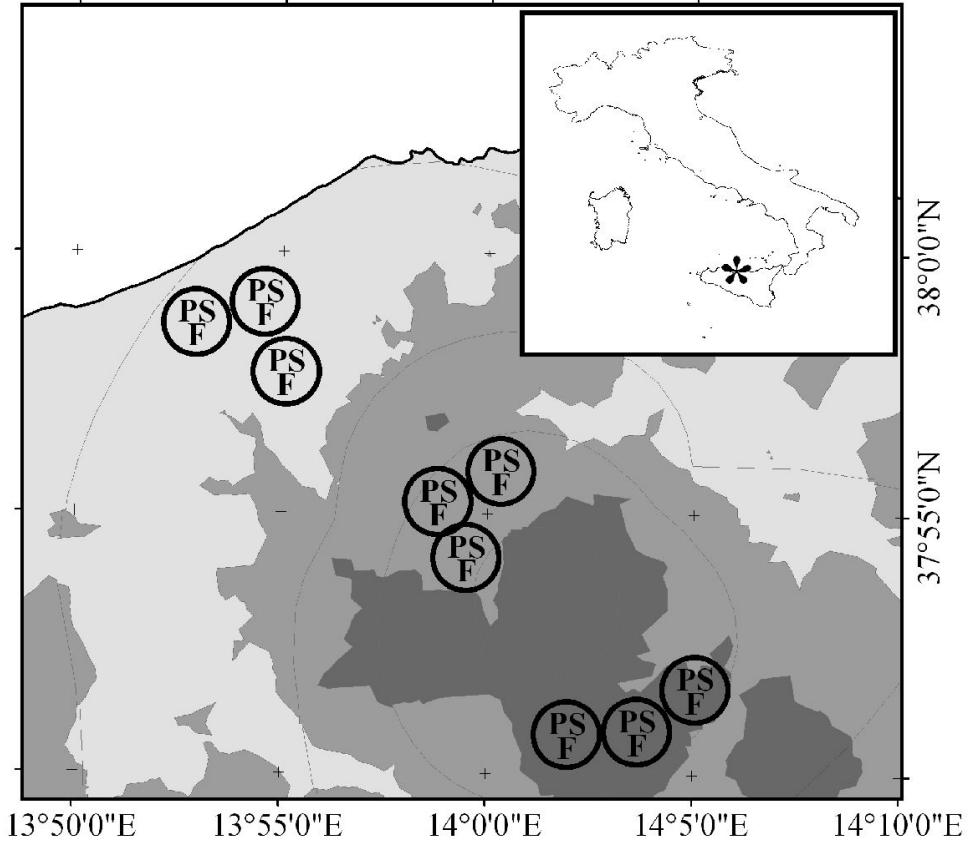

Fig. 1 - Location of the study site within the Italian territory (asterisk in inset) and of the experimental areas (circles) within the study site. Successional stages: $(\mathrm{P})$ : pasture; (S): shrubland; (F): forest. Bioclimatic thermotype is represented by a grey scale: (dark grey): supramediterranean; (medium grey): mesomediterranean; (light grey): thermomediterranean. Grey lines delimit ombrotype: with decreasing altitude, the ombrotypes are upper humid, lower humid, upper subhumid, lower subhumid, and upper arid (climatic data after Drago et al. 2002).

composability of aboveground litter in a Mediterranean mountain area was higher for grasslands than shrublands. The same authors concluded that a decrease in the decomposition rates of the aboveground litter was the main cause for a net increase in $\mathrm{C}$ sequestration upon shrub encroachment into grasslands. These observations are strongly linked to the activity of soil decomposer communities because there are close interactions and feedback between litter quality, plant community composition, and soil microbial activity and diversity (Liao \& Boutton 2008).

In this paper, we investigate the effects of woody plant colonization after grazing cessation on soil and aboveground litter $\mathrm{C}$ and $\mathrm{N}$ content along a bioclimatic transect in a semi-arid environment. Bioclimatic classifications were used to subdivide the investigated territory into areas sharing homogeneous conditions for the growth of plant communities. By using a bioclimatic transect, we could directly relate variations in $\mathrm{C}$ and $\mathrm{N}$ contents to temperature and rainfall regimes, and indirectly relate these variations to plant community composition. We attempted to determine whether soil $\mathrm{C}$ and $\mathrm{N}$ storage are affected by stage of succession and bioclimate. To interpret our results, we also collected data on the changes of litter quality and mass during succession and among bioclimates. We focused on two main questions:

- Is there an overall influence of bioclimate on soil and litter $\mathrm{C}$ and $\mathrm{N}$ content?

- Do soil and litter $\mathrm{C}$ and $\mathrm{N}$ dynamics during succession differ among bioclimates?

\section{Materials and Methods}

\section{Study site}

The study site was located in the Madonie Mts., a calcareous massif of northern Sicily (Italy - Fig. 1), where large areas of marginal agricultural land were abandoned during the second half of the $20^{\text {th }}$ century. Because of their elevation gradient, ranging from sea level to 1979 m a.s.l. (Pizzo Carbonara), the Madonie Mts. have a variety of bioclimatic conditions. To characterize local bioclimate, we used data reported by Drago et al. (2002). These authors developed an accurate geostatistical model of Sicilian bioclimatic belts by interpolating data collected over 30 years by thermo-pluviometric stations all across the island. An overview of the potential vegetation of Sicily (Bazan et al. 2010) recently confirmed this interpretation of the climatic data.

To characterize local bioclimates, RivasMartínez's (2004) indexes were used: the ombrotype is based on the mean annual precipitation, while the thermotype is based on the temperature regime as indicated by the thermal index $I_{\mathrm{t}}$, which is calculated as follows (eqn. 1):

$$
I_{t}=(T+M+m) \cdot 10
$$

where $T$ is the mean annual temperature $\left({ }^{\circ} \mathrm{C}\right) ; M$ is the mean of the maximum temperatures of the coldest month $\left({ }^{\circ} \mathrm{C}\right)$, and $m$ is the mean of the minimum temperatures of the coldest month $\left({ }^{\circ} \mathrm{C}\right)$.

Our analysis showed that the study site is characterized by a combination of three thermotypes (supra-, meso-, and thermo-mediterranean) and five ombrotypes (upper humid, lower humid, upper subhumid, lower subhumid, and upper arid). We then selected three experimental areas (Fig. 1) within each of the three most representative bioclimates, i.e., within the "supramediterranean-lower humid" (henceforth: "supra"), "mesomediterranean-lower humid" ("meso"), and "thermomediterranean-lower subhumid" ("thermo") belts (Tab. 1). In each experimental area, three successional stages representing a (post-) pasture succession series were selected: (1) grazed pasture without woody species; (2) shrubland; and (3) forest. Successional stages in each experimental area were located in direct proximity to each other and

Tab. 1 - Environmental features of the experimental areas. Abbreviations: (supra): Supramediterranean-Lower Humid; (meso): Mesomediterranean-Lower Humid; (thermo): Thermomediterranean-Lower Subhumid; (T): mean annual temperature; $(\mathrm{R})$ : mean annual rainfall; (UTM): UTM coordinates of the areas; (Alt): altitude. Climatic data after Drago et al. (2002); soil data after Carta dei suoli della Sicilia (Unpublished, Ass. Reg. Ris. Agr. e Al., Regione Siciliana, Palermo, Italy); soil classification after WRB (1998).

\begin{tabular}{lcclcc}
\hline Bioclimate & $\begin{array}{c}\mathbf{T} \\
\left({ }^{\circ} \mathbf{C}\right)\end{array}$ & $\begin{array}{c}\mathbf{R} \\
(\mathbf{m m})\end{array}$ & Soil & UTM & $\begin{array}{c}\text { Alt } \\
(\mathbf{m} \text { a.s.l.) }\end{array}$ \\
\hline Supra & 11 & 1100 & Haplic Luvisols & $417040 \mathrm{E} / 4190155 \mathrm{~N}$ & 1.354 \\
& & & Profondic & $417577 \mathrm{E} / 4190123 \mathrm{~N}$ & 1.296 \\
& & & & $420185 \mathrm{E} / 4191819 \mathrm{~N}$ & 1.222 \\
\hline Meso & \multirow{2}{*}{14} & \multirow{2}{*}{ Endoleptic Regosols } & $412104 \mathrm{E} / 4195084 \mathrm{~N}$ & 1.050 \\
& & & Eutric & $411782 \mathrm{E} / 4197410 \mathrm{~N}$ & 723 \\
& & & $410396 \mathrm{E} / 4198116 \mathrm{~N}$ & 674 \\
\hline Thermo & \multirow{2}{*}{650} & Endoleptic Regosols & $404329 \mathrm{E} / 4201567 \mathrm{~N}$ & 295 \\
& & & Eutric & $402264 \mathrm{E} / 4203765 \mathrm{~N}$ & 177 \\
& & & $402902 \mathrm{E} / 4203630 \mathrm{~N}$ & 175 \\
\hline
\end{tabular}


characterized by comparable abiotic conditions (aspect, slope, soil type, rock outcrop, stone cover, etc). Soil homogeneity among the three experimental areas within the same bioclimate was checked visually.

Plant community composition differed depending on successional stage and bioclimate (Tab. 2). All sampled successional stages showed vegetation cover values of $95 \pm 5 \%$ (mean \pm standard deviation), with a maximum of $5 \%$ cover of rock outcrop and stones. Pastures were dominated by grasses and perennial herbs (Tab. 2), with woody cover $<5 \%$. Shrublands were dominated by Rosaceae in "supra", by Rosaceae and Spartium junceum L. in "meso", and by sclerophyllous shrubs (Rhamnus alaternus L., Pistacia lentiscus L.) and Spartium junceum in "thermo". In all shrublands, shrubs represented a woody cover of $65 \pm 15 \%$, while the remaining part was covered by annual and perennial herbs and grasses. Forests were dominated by beech in "supra", by downy oak and holm oak in "meso", and by downy oak in "thermo". Tree cover in all bioclimates was $90 \pm 5 \%$, with intermediate values of understorey shrub $(30 \pm 15 \%)$ and herb $(20 \pm 10 \%)$ cover. According to Bazan et al. (2010) and considering the differences between the three bioclimatic belts, potential vegetation of the selected experimental areas was ascribed to the following associations: (a) "supra": Ilici aquifolii-Quercetum aus trotyrrhenicae Brullo \& Marcenò in Brullo 1984 and Anemono apenninae-Fagetum sylvaticae (Gentile 1969) Brullo $1984 \mathrm{em}$ Ubaldi et al. 1987, both referred to the alliance Doronico-Fagion (Gentile 1969) Ubaldi et al. 1990; (b) "meso": Aceri campestrisQuercetum ilicis Brullo 1984 and Rhamno alaterni-Quercetum ilicis Brullo \& Marcenò
1985, both belonging to the alliance Quercion ilicis Br.-Bl. ex Molinier 1934 em. Rivas-Martínez 1975; and (c) "thermo": Oleo sylvestris-Quercetum virgilianae Brullo 1984 (Quercion ilicis).

Abandonment age of the sampled successional stages was determined by evaluating aerial photographs taken in 1955 (produced by Istituto Geografico Militare, Florence, Italy) and 1987 (Regione Siciliana, Palermo, Italy). All sampled forests had been abandoned for more than 50 years, while all sampled shrublands had been abandoned for 25-50 years. Areas that were sampled as forests in $2011 \mathrm{had}$, in 1955, $15 \pm 5 \%, 20 \pm$ $5 \%$, and $10 \pm 5 \%$ tree cover and $75 \pm 20 \%$, $50 \pm 10 \%$, and $45 \pm 40 \%$ shrub cover in "supra", "meso", and "thermo", respectively. The same areas in 1987 were characterized by $70 \pm 35 \%, 90 \pm 10 \%$, and $50 \pm 30 \%$ tree cover and $30 \pm 25 \%, 10 \pm 5 \%$, and $40 \pm 15 \%$ shrub cover, respectively. All areas that were sampled as shrublands in 2011 were grazed pastures (woody cover $<5 \%$ ) in 1955 , and in 1987 had $25 \pm 20 \%, 35 \pm 5 \%$, and $25 \pm 5 \%$ shrub cover and no tree cover in "supra", "meso", and "thermo", respectively.

\section{Soil sampling and analysis}

Soil was sampled according to the protocol of the Italian National Inventory of Forests and Forest Carbon Pools (Gasparini et al. 2008). Litter on soil was collected within a $30 \times 30 \mathrm{~cm}$ square, and litter mass was expressed as $\mathrm{t} \mathrm{ha}^{-1}$. After the litter was removed, mineral soil samples were collected at depths of $0-10 \mathrm{~cm}$ and $10-30 \mathrm{~cm}$ using a 340 and a $680 \mathrm{~cm}^{3}$ cylinder, respectively. In each successional stage, three soil samples (replications) were collected at approximately $10-\mathrm{m}$ intervals along a linear transect (3 bioclimates $\times 3$ experimental areas $\times 3$ succession stages $\times 2$ depths $\times 3$ replications $=$ 162 soil samples). In shrublands, soil samples were collected under the canopies of randomly selected shrub individuals.

Litter and soil samples were stored in a bag and immediately send to the laboratory. Litter samples were oven dried $\left(55^{\circ} \mathrm{C}\right)$, weighed, and then analysed for $\mathrm{C}$ and $\mathrm{N}$ content. Soil samples were gently broken, passed through a $2-\mathrm{mm}$ sieve, air dried, ground to a fine powder, treated with $\mathrm{HCl}$ 2:1 to remove carbonates (ISO 10694 1995), and then analysed for $\mathrm{C}$ and $\mathrm{N}$ content using a CHN-Elemental Analyzer. SOC content was first expressed as a percentage ( $\mathrm{g}$ of $\mathrm{C}$ per $100 \mathrm{~g}$ of dry soil $\times 100)$ and then converted to $\mathrm{Mg}$ per hectare based on bulk density (BD) and soil depth using the following equation (eqn. 2):

$$
C_{\text {stock }}\left(\mathrm{Mgha}^{-1}\right)=B D \cdot C_{\text {conc }} \cdot D \cdot C F_{\text {coarse }}
$$

where $B D$ is bulk density $\left(\mathrm{g} \mathrm{cm}^{-3}\right), C_{\text {conc }}$ is carbon concentration $(\mathrm{g} / 100 \mathrm{~g}), D$ is depth thickness $(\mathrm{m})$, and $C F_{\text {coarse }}$ is a correction factor [1- (gravel \% + stone $\%$ ) /100].

Soil bulk density was measured using the tube core method (Blake \& Hartge 1986) and was based on the volume of the collected sample and the weight of dry soil in the sample.

\section{Data evaluation}

We used ANOVAs to compare the effects of bioclimate (supra-, meso-, and thermomediterranean), successional stage (pasture, shrubland, and forest), soil depth $(0-10 \mathrm{~cm}$ and $10-30 \mathrm{~cm})$, and their interactions on SOC stock, BD, soil $\mathrm{N}$ content, soil $\mathrm{C} / \mathrm{N}$, aboveground litter $\mathrm{C}$ content, aboveground litter $\mathrm{N}$ content, and aboveground litter $\mathrm{C} / \mathrm{N}$

Tab. 2 - Dominant plant species (in alphabetical order) in each successional stage of the studied bioclimates (information from the three replications per successional stage was grouped). Abbreviations for bioclimates are explained in Tab. 1.

\begin{tabular}{|c|c|c|}
\hline Bioclimate & $\begin{array}{l}\text { Successional } \\
\text { stage }\end{array}$ & Dominant plant species \\
\hline \multirow[t]{3}{*}{ Supra } & Pasture & $\begin{array}{l}\text { Carduus pycnocephalus L., Carlina nebrodensis DC., Centaurea solstitialis L. subsp. schouwii (DC.) } \\
\text { Dostál, Eryngium amethystinum L., Juncus effusus L., Lolium perenne L., Prangos ferulacea (L.) Lindl., } \\
\text { Schedonorus arundinaceus (Schreb.) Dumort. }\end{array}$ \\
\hline & Shrubland & $\begin{array}{l}\text { Astracantha nebrodensis (Guss.) Greuter, Crataegus laevigata (Poir.) DC., Euphorbia rigida M. Bieb., } \\
\text { Prunus spinosa L., Pyrus communis L., Rosa canina L., Rubus canescens DC. }\end{array}$ \\
\hline & Forest & $\begin{array}{l}\text { Euphorbia meuselii Raimondo \& Mazzola, Fagus sylvatica L., Hedera helix L., Ilex aquifolium L., Quer- } \\
\text { cus petraea (Mattuschka) Liebl. subsp. austrotyrrhenica Brullo, Guarino \& Siracusa }\end{array}$ \\
\hline \multirow[t]{3}{*}{ Meso } & Pasture & $\begin{array}{l}\text { Bromus hordeaceus L., Calamintha nepeta (L.) Savi, Centaurea calcitrapa L., Convolvulus arvensis L., } \\
\text { Eryngium campestre L., Euphorbia rigida M. Bieb., Ferula communis L., Foeniculum vulgare L., Lolium } \\
\text { perenne L., Onopordum illyricum L., Thapsia garganica L. }\end{array}$ \\
\hline & Shrubland & $\begin{array}{l}\text { Daphne gnidium L., Crataegus laevigata (Poir.) DC., Pyrus amygdaliformis Vill., Rosa canina L., Rubus } \\
\text { ulmifolius Schott, Spartium junceum L. }\end{array}$ \\
\hline & Forest & Acer campestre L., Quercus ilex L., Quercus virgiliana Ten. \\
\hline \multirow[t]{3}{*}{ Thermo } & Pasture & $\begin{array}{l}\text { Ampelodesmos mauritanica (Poir.) T. Dur. \& Schinz, Arundo collina Ten., Carlina sicula Ten., Dasypyr- } \\
\text { um villosum (L.) Borbás, Dittrichia viscosa (L.) Greuter, Foeniculum vulgare L., Galactites tomentosa (L.) } \\
\text { Moench }\end{array}$ \\
\hline & Shrubland & $\begin{array}{l}\text { Asparagus acutifolius L., Pistacia lentiscus L., Pyrus amygdaliformis Vill., Rhamnus alaternus L., Sparti- } \\
\text { um junceum L. }\end{array}$ \\
\hline & Forest & Olea europaea L. var. sylvestris (Mill.) Lehr., Quercus virgiliana (Ten.) Ten. \\
\hline
\end{tabular}



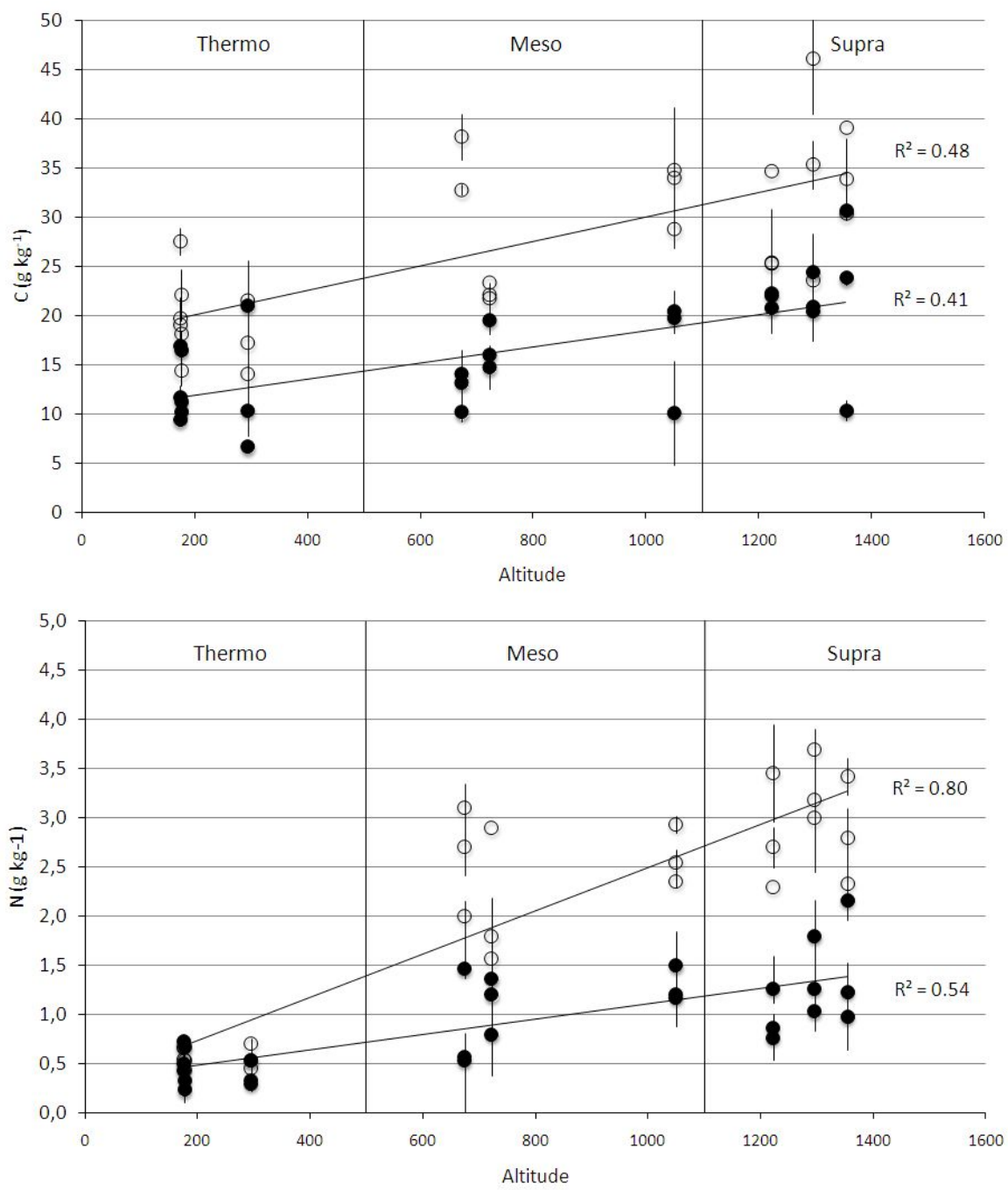

Fig. 2 - Soil organic carbon stock (C - above) and soil nitrogen content (N - below) along an altitudinal gradient across all successional stages (pasture, shrubland, forest) at two soil depths $(0-10 \mathrm{~cm}$ : empty circles; $10-30 \mathrm{~cm}$ : full circles). The gradient included three bioclimates, which are indicated by the vertical lines. Each point represents the mean of nine replicate soil samples taken in every successional stage, and bars represent standard deviation.

ratio. Because no statistical differences were and considered as replicates, thus obtaining found among the same successional stage 9 replications per successional stage (3 exwithin each bioclimate (data not shown), perimental areas $\times 3$ replications). ANOVAs stage data were pooled within bioclimates were also used to test for statistical diffe- rences among successional stages within each bioclimate. Means were compared with an adjusted Tukey's least significant difference (LSD) test. In addition, regression analyses were performed to determine the significance of relationships among altitude (m a.s.1.) and soil characteristics (SOC, N, C/N ratio) or litter $\mathrm{C} / \mathrm{N}$ ratio.

We also computed an average index of SOC content change (CCI, Carbon Change Index) from early to late successional stages, respectively, as follows (eqn. 3):

$$
C C I=\frac{C_{\text {late }}-C_{\text {early }}}{C_{\text {early }}}
$$

where $C_{\text {older }}$ is the SOC content at late successional stages, and $C_{\text {early }}$ is the SOC content at early successional stages. A regression analysis was then performed to determine whether $C C I$ was related to altitude. A similar analysis was performed for $\mathrm{N}$ content (nitrogen change index, $N C I$ ).

All analyses were carried out using the SAS statistical package (SAS Institute 2001).

\section{Results}

Overall differences among bioclimates All measured soil and litter parameters differed among bioclimates (Tab. 3). SOC and soil $\mathrm{N}$ increased from "thermo" to "supra" at both soil depths (Fig. 2). C stock and $\mathrm{N}$ content changed significantly with soil depth (Tab. 3): the $0-10 \mathrm{~cm}$ depth contained more $\mathrm{C}$ and $\mathrm{N}$ than the $10-30 \mathrm{~cm}$ depth (Fig. 2). Litter $\mathrm{C} / \mathrm{N}$ ratio was lower in "supra" than in "meso" and "thermo", and mean soil $\mathrm{C} / \mathrm{N}$ ratio was lower in "supra" and "meso" than in "thermo" (Tab. 4, Fig. $3)$.

\section{Differences among successional stages within bioclimates}

Only the $0-10 \mathrm{~cm}$ soil depth showed significant differences for the measured parameters among successional stages within bioclimates. The $C C I$ showed a significant trend only for the $0-10 \mathrm{~cm}$ depth, with negative

Tab. 3 - Effects of bioclimate, successional stage, and soil depth as indicated by $P$ values from ANOVAs. The factorial analysis included main effects and interactions of bioclimate (supra-, meso-, and thermomediterranean), successional stage (pasture, shrubland, and forest), and soil depth (0-10 cm and 10-30 cm). (SOC): soil organic carbon stock; (BD): bulk density; (Soil N): soil nitrogen content; (Soil C/N): ratio of carbon and nitrogen in soil; (Litter C): litter carbon stock; (Litter N): litter nitrogen stock; (Litter $\mathrm{C} / \mathrm{N})$ ): ratio of carbon and nitrogen in litter.

\begin{tabular}{|c|c|c|c|c|c|c|c|}
\hline \multirow{2}{*}{$\begin{array}{l}\text { Source of } \\
\text { variance }\end{array}$} & \multicolumn{7}{|c|}{ Dependent variable and $P$ values } \\
\hline & SOC & BD & Soil N & Soil C/N & Litter C & Litter $\mathbf{N}$ & Litter $\mathbf{C} / \mathbf{N}$ \\
\hline Replication & 0.3101 & 0.3258 & 0.0123 & 0.1412 & 0.0111 & 0.3271 & 0.1211 \\
\hline Bioclimate (B) & $<0.0001$ & 0.0002 & $<0.0001$ & $<0.0001$ & 0.0008 & 0.0003 & 0.0087 \\
\hline Succession (S) & 0.3075 & $<0.0001$ & 0.0017 & 0.2475 & $<0.0001$ & 0.0023 & 0.00043 \\
\hline Depth (D) & $<0.0001$ & $<0.0001$ & $<0.0001$ & 0.2629 & - & - & - \\
\hline$B * S$ & 0.0147 & 0.0934 & 0.0145 & 0.8186 & 0.0031 & $<0.0001$ & 0.0065 \\
\hline$B * D$ & 0.093 & 0.1407 & $<.0001$ & 0.0001 & - & - & - \\
\hline$S^{*} \mathrm{D}$ & 0.1877 & 0.7563 & 0.0283 & 0.4919 & - & - & - \\
\hline $\mathrm{B} * \mathrm{~S} * \mathrm{D}$ & 0.0542 & 0.9618 & 0.1066 & 0.0453 & - & - & - \\
\hline
\end{tabular}


Fig. 3 - Soil carbon stock at 0-10 $\mathrm{cm}$ soil depth (empty circles, solid regression line), litter $\mathrm{C} / \mathrm{N}$ ratio (full black circles, thick solid regression line), and soil $\mathrm{C} / \mathrm{N}$ ratio (full grey circles, dashed regression line) along an altitudinal gradient. The gradient included three bioclimates, which are indicated by the vertical lines. Each point represents a mean of three replicate soil samples taken in every successional stage, and bars represent standard deviation.

Fig. 4 - Carbon change index along an altitudinal gradient at $0-10 \mathrm{~cm}$ soil depth. The gradient included three bioclimates, which are indicated by the vertical lines. Each point represents a mean of three replications, and bars represent standard deviation.
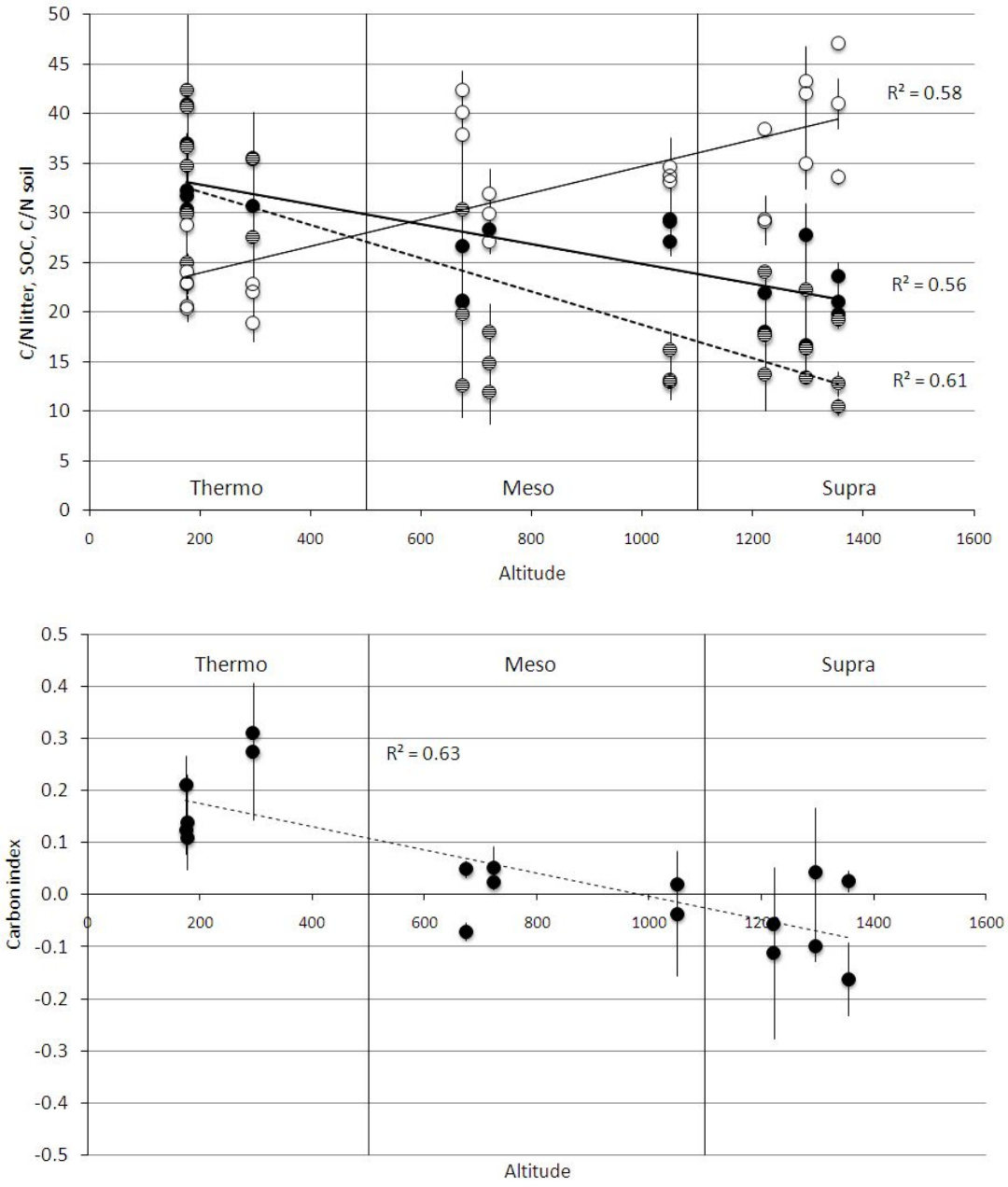

values in "supra", values near zero in "meso", and positive values in "thermo" (Fig. 4). The $N C I$ did not show any significant trend.

At $0-10 \mathrm{~cm}$ soil depth, secondary succession in "supra" led to a decrease in SOC from pasture to shrubland and then to an increase from shrubland to forest (Tab. 4). Interestingly, SOC values were lower for forests than pastures in "supra". In "meso", however, SOC did not vary with secondary succession, while in "thermo", SOC values increased from pasture to shrubland but did not significantly change from shrubland to forest. "Thermo" forests had the lowest SOC values of all the considered forest communities.

Soil N, on the other hand, increased with succession in "supra", while in "meso" and "thermo" it decreased from pastures to shrubland and increased from shrubland to forest. Soil $\mathrm{N}$ was about 6-7 times lower in "thermo" forests than in "supra" ones.

Soil $\mathrm{C} / \mathrm{N}$ ratio decreased with succession in "supra", but showed no significant trend in "meso" and tended to increase with succession in "thermo". Soil C/N ratio values were similar for "supra" and "meso" but were

Tab. 4 - Mean values of soil (0-10 cm depth) and litter parameters for the three bioclimates and three successional stages. Means in columns with different uppercase or lowercase letters are statistically different at $P<0.01$ : lowercase letters are used to compare successional stages within a bioclimate, and uppercase letters to compare the overall means of bioclimates; (ns): not significant; (Litter): Litter mass. Other abbreviations as in Tab. 3.

\begin{tabular}{|c|c|c|c|c|c|c|c|c|c|}
\hline Bioclimate & $\begin{array}{l}\text { Successional } \\
\text { stage }\end{array}$ & $\begin{array}{c}\text { SOC } \\
\left(\text { t ha }^{-1}\right)\end{array}$ & $\begin{array}{c}\text { BD } \\
\left(\mathrm{g} \mathrm{cm}^{-3}\right)\end{array}$ & $\begin{array}{l}\text { Soil N } \\
\left(\mathrm{g} \mathrm{kg}^{-1}\right)\end{array}$ & $\begin{array}{l}\text { Soil } \\
\text { C/N }\end{array}$ & $\begin{array}{l}\text { Litter } \\
\left(\text { t ha }^{-1}\right)\end{array}$ & $\begin{array}{c}\text { Litter C } \\
\left(\mathrm{t} \mathrm{ha}^{-1}\right)\end{array}$ & $\begin{array}{c}\text { Litter N } \\
\left(\text { t ha }^{-1}\right)\end{array}$ & $\begin{array}{l}\text { Litter } \\
\text { C/N }\end{array}$ \\
\hline \multirow[t]{4}{*}{ Supra } & Pasture & $42.84^{a}$ & $1.22^{\mathrm{a}}$ & $2.54^{\mathrm{c}}$ & $15.72^{a}$ & $2.56^{\mathrm{c}}$ & $0.64^{b}$ & $0.02^{c}$ & $19.2^{\mathrm{c}}$ \\
\hline & Shrubland & $32.30^{\mathrm{b}}$ & $1.10^{\mathrm{b}}$ & $3.03^{\mathrm{b}}$ & $14.22^{b}$ & $6.17^{\mathrm{b}}$ & $4.56^{\mathrm{a}}$ & $0.99^{\mathrm{a}}$ & $23.3^{b}$ \\
\hline & Forest & $37.41^{\mathrm{c}}$ & $1.05^{\mathrm{c}}$ & $3.50^{\mathrm{a}}$ & $13.02^{\mathrm{c}}$ & $9.29^{\mathrm{a}}$ & $3.22^{\mathrm{a}}$ & $0.43^{\mathrm{b}}$ & $25.1^{\mathrm{a}}$ \\
\hline & Mean & $37.30^{\mathrm{A}}$ & $1.13^{\mathrm{B}}$ & $2.97^{\mathrm{A}}$ & $14.48^{\text {в }}$ & $5.59^{\text {в }}$ & $2.76^{\mathrm{B}}$ & $0.48^{\mathrm{A}}$ & $22.2^{\mathrm{C}}$ \\
\hline \multirow[t]{4}{*}{ Meso } & Pasture & $34.59^{\mathrm{ns}}$ & $1.21^{\mathrm{a}}$ & $2.40^{\mathrm{b}}$ & $12.53^{\mathrm{ab}}$ & $4.38^{\mathrm{c}}$ & $1.64^{\mathrm{c}}$ & $0.09^{\mathrm{c}}$ & $29.7^{\mathrm{ns}}$ \\
\hline & Shrubland & $34.20^{\mathrm{ns}}$ & $1.17^{\mathrm{b}}$ & $2.05^{\mathrm{c}}$ & $15.61^{\mathrm{a}}$ & $8.38^{a}$ & $3.36^{\mathrm{b}}$ & $0.38^{\mathrm{b}}$ & $29.7^{\mathrm{ns}}$ \\
\hline & Forest & $34.86^{\mathrm{ns}}$ & $1.12^{\mathrm{c}}$ & $2.84^{\mathrm{a}}$ & $11.87^{b}$ & $6.66^{\mathrm{b}}$ & $4.59^{\mathrm{a}}$ & $0.82^{\mathrm{a}}$ & $29.8^{\mathrm{ns}}$ \\
\hline & Mean & $34.58^{\mathrm{A}}$ & $1.17^{\mathrm{B}}$ & $2.41^{\mathrm{A}}$ & $13.29^{\text {в }}$ & $6.22^{\text {в }}$ & $3.40^{\mathrm{A}}$ & $0.49^{\mathrm{A}}$ & $30.5^{\text {в }}$ \\
\hline \multirow{4}{*}{ Thermo } & Pasture & $20.72^{a}$ & $1.35^{\mathrm{a}}$ & $0.58^{\mathrm{a}}$ & $30.03^{b}$ & $7.41^{\mathrm{b}}$ & $2.59^{\mathrm{c}}$ & $0.21^{\mathrm{b}}$ & $34.0^{c}$ \\
\hline & Shrubland & $24.99^{b}$ & $1.23^{\mathrm{b}}$ & $0.49^{\mathrm{b}}$ & $43.34^{\mathrm{a}}$ & $9.75^{\mathrm{a}}$ & $4.23^{\mathrm{a}}$ & $0.51^{\mathrm{a}}$ & $41.7^{b}$ \\
\hline & Forest & $22.11^{a b}$ & $1.06^{\mathrm{c}}$ & $0.58^{\mathrm{a}}$ & $46.68^{a}$ & $9.06^{\mathrm{a}}$ & $3.80^{\mathrm{b}}$ & $0.41^{\mathrm{a}}$ & $51.0^{\mathrm{a}}$ \\
\hline & Mean & $22.67^{\mathrm{B}}$ & $1.23^{\mathrm{A}}$ & $0.55^{\text {в }}$ & $38.81^{\mathrm{A}}$ & $8.70^{\mathrm{A}}$ & $3.51^{\mathrm{A}}$ & $0.37^{\mathrm{B}}$ & $41.9^{\mathrm{A}}$ \\
\hline
\end{tabular}


more than two times greater in "thermo" than in "supra" and "meso".

C stocks in litter increased significantly with succession in "meso", while in "thermo" litter C increased from pasture to shrubland and decreased from shrubland to forest. In "supra", litter C increased from pasture to shrubland but not from shrubland to forest. Litter N increased with succession in "meso" but peaked in shrublands in "supra"; litter N in "thermo" increased from pasture to shrubland but not from shrubland to forest.

Litter $\mathrm{C} / \mathrm{N}$ ratio increased in "supra" and "thermo" from pasture to shrubland and from shrubland to forest, but did not change significantly with succession in "meso". "Supra" succession was characterized by the lowest litter $\mathrm{C} / \mathrm{N}$ ratios with respect to the other two bioclimates. The largest increase in $\mathrm{C} / \mathrm{N}$ ratio occurred in "thermo" secondary succession.

\section{Discussion}

\section{Overall differences among bioclimates}

The results obtained in this investigation confirmed an overall influence of bioclimate on soil and litter $\mathrm{C}$ and $\mathrm{N}$ content. Soil $\mathrm{C}$ stocks and $\mathrm{N}$ contents decreased from the colder, wetter climate to the warmer, drier climate. This observation can be explained by the combined effects of litter quality and limiting abiotic factors, which vary along an elevation gradient (Knoepp et al. 2000). Because net primary production in semi-arid environments can be limited by high temperatures and drought (Dai \& Huang 2006), the lower quantity of litterfall may account for lower soil $\mathrm{C}$ and $\mathrm{N}$ contents observed in thermomediterranean areas than in the mesoand supramediterranean areas. In contrast to soil $\mathrm{C}$ and $\mathrm{N}$ content, litter mass was greater in the warmer, drier thermomediterranean areas than in the colder, wetter meso- and supramediterranean areas. The latter findings may be interpreted as an effect of soil moisture, in that low soil moisture in drough periods may reduce litter decay rates by influencing the activity of soil microorganisms (Hontoria et al. 1999, Mayer 2008, Incerti et al. 2011).

In addition, different bioclimates correspond to different vegetation types, which in turn produce litter of different quality. Indeed, mean $\mathrm{C} / \mathrm{N}$ ratios were higher in "thermo" litter than in "supra" or "meso" litter, suggesting that reduced litter quality could have decreased the rate at which "thermo" litter decayed and thereby contributed to a reduced soil $\mathrm{C}$ and $\mathrm{N}$ accumulation in that bioclimate. Drier and warmer sites are also characterized by higher cover values of plants with an evergreen habit, which is another trait related to reduced litter quality (Pérez-Harguindeguy et al. 2000).
Differences among successional stages within bioclimates

Our study confirmed that soil and litter C and $\mathrm{N}$ dynamics differ along the succession. Changes in $\mathrm{C}$ stocks and $\mathrm{N}$ contents in relation to successional stage may be due to change in plant community composition (Koukoura et al. 2003, Prévosto et al. 2006), change in litter quality (also due to an increase in the content of secondary compounds, such as lignin or polyphenolic substances - Cortez et al. 2007, Montané et al. 2010), increases in soil moisture and decreases in soil temperature with shrub encroachment (Carl \& Richter 1989, Franco-Pizana et al. 1996), change in soil microbial (Rutigliano et al. 2004, Fioretto et al. 2009, Jangid et al. 2011) and macrofaunal (Decaëns et al. 1998) community structure, and decreases in bulk density following grazing abandonment and subsequent increases in the mineralization of soil organic matter (Mayer 2008).

Changes in $\mathrm{C}$ stocks and $\mathrm{N}$ contents with succession were greater in the $0-10 \mathrm{~cm}$ depth layer than at 10-30 cm depth both in the current study and in previous ones (Liao \& Boutton 2008, Foote \& Grogan 2010). This may be due to litter, which causes the upper mineral soil layers to respond more rapidly than deeper layers to changes in aboveground $\mathrm{C}$ and $\mathrm{N}$ inputs. Moreover, bulk density decreased after grazing cessation (i.e., with the cessation of trampling) in the uppermost mineral soil horizon, but not in the deeper layers (Prévosto et al. 2006).

The successional differences in $\mathrm{C}$ stock and $\mathrm{N}$ content between the studied bioclimates may be due to the contrasting effects of litter transformability into humified organic matter and input mass, soil microclimate and soil $\mathrm{C} / \mathrm{N}$ ratio, and the interaction among these factors. In general, the amount of $\mathrm{C}$ input into soil mineral layers is enhanced by the increase of the mass of aboveground litter, by more favorable soil microclimate for the transformation of litter to particulate organic matter, and by lower litter $\mathrm{C} / \mathrm{N}$ ratios. Thus, ceteris paribus, all the above factors may determine a SOC lift up. In contrast, the presence of lignin or other secondary compounds in the litter may hamper its transformation as humified organic matter, lessening $\mathrm{C}$ inputs into soil mineral layers and thus reducing SOC. Lower soil $\mathrm{C} / \mathrm{N}$ ratios and higher mineralization rates of soil organic matter with soil decompaction after grazing cessation would also decrease SOC. We hypothesize that the importance of some of these factors changes with bioclimate. In fact, our results indicate that SOC in "supra" succession is most influenced by changes in litter quality, while SOC in "thermo" succession is most influenced by changes in microclimate. Succession in "supra" started from pastures with high SOC stocks, high-quality litter, and a high soil $\mathrm{C} / \mathrm{N}$ ratio. The subsequent decrease of SOC with shrub encroachment is caused by a decrease in litter transformability and an increase in mineralization rates of soil humified organic matter after soil $\mathrm{C} / \mathrm{N}$ and bulk density decrease, which outweigh even the strong increase in litter $\mathrm{C}$ input occurring with succession from herb-dominated pasture to shrubland in the "supra" bioclimate. The subsequent increase of SOC with succession from shrubland to forest, however, is not driven by the same factors, because litter quality, soil $\mathrm{C} / \mathrm{N}$ ratio, and bulk density decreased further. Although increased litter input might account for the SOC increase, we did not observe a significant change of litter $\mathrm{C}$ from shrubland to forest. It follows that SOC was influenced by some unknown factor that was not measured in our study.

In contrast to SOC in "supra", SOC in "thermo" increased during shrub encroachment into grasslands. Because soil $\mathrm{C} / \mathrm{N}$ ratio strongly increased at the same time, the SOC increase may be due to reduced mineralization rates of soil humified organic matter. The observed reduction in litter transformability into humified organic matter apparently had a weaker effect on SOC dynamics in "thermo" than in "supra". In "thermo", the limiting climatic conditions, i.e., low soil moisture and high temperature, could have played a major role in SOC increase because they reduce the rate of decay (Hontoria et al. 1999) especially in the pastures, where no shrub layer intercepts solar radiation and mitigates climatic conditions. The effects of low soil moisture and high temperature, however, are increasingly moderated as succession proceeds, and shrubs and then trees intercept the light and moderate the microclimate for litter decomposers (Garcia-Pausas et al. 2004).

Values of litter $\mathrm{C} / \mathrm{N}$ observed in this study are comparable to those reported by other studies of thermomediterranean sites (Garcia-Pausas et al. 2004, Rodríguez Pleguezuelo et al. 2009, Castro et al. 2010). Contrastingly, we observed values for soil $\mathrm{C} / \mathrm{N}$ higher than those in comparable studies. Previous investigations reported soil $\mathrm{C} / \mathrm{N}$ ratios ranging from 10 to 21 for thermomediterranean grasslands (Fanelli et al. 2008, Marzaioli et al. 2010), shrublands (Bonet 2004, Sardans et al. 2008), and forests (Pinzari et al. 1999). The high soil $\mathrm{C} / \mathrm{N}$ that we observed in pastures may be due to wildfires (commonly linked to grazing activity in Sicily), and the subsequent $\mathrm{N}$ leaching from soil (Romanyà et al. 2001). The plant communities in thermomediterranean pastures are dominated by graminoid species with lower $\mathrm{N}$ leaf contents and litter decomposition than forbs (Cornwell et al. 2008), while meso- and supramediterranean pastures are dominated by forbs. Because the sclerophyl- 
lous, evergreen woody species that colonize thermomediterranean pastures are also characterized by low $\mathrm{N}$ contents (Kazakou et al 2009), the transformation of their litter into humified organic matter immobilizes soil $\mathrm{N}$ (Papa et al. 2008). As a result, soil $\mathrm{C} / \mathrm{N}$ increases with shrub encroachment.

As opposed to succession in "supra", succession from shrubland to forest in "thermo" was not associated with an increase in SOC The negative effect on SOC that could have been expected from the strong decrease of litter transformability (probably due to the growing cover of evergreen sclerophyllous species) and from a decrease in litter $\mathrm{C}$ input and bulk density, was clearly counterbalanced by the simultaneous reduction of mineralization rates of soil humified organic matter (due to soil $\mathrm{C} / \mathrm{N}$ increase) and probably by soil microclimate or some other factors not measured in our study. Given the reduction of litter $\mathrm{C}$ input in the transition from shrublands to forests, we hypothesize that the increasing shrub cover could create more favorable conditions for the transformation of the high amounts of litter accumulated during shrub encroachment, whose decaying in "thermo" is hampered by the low moisture and high temperatures. Consequently, the substantial increase in the decay of litter mass would result in the substantial increase of inputs into the SOC pool.

Under "meso" conditions, the SOC stock remained stable along the succession gradient. Because litter $\mathrm{C} / \mathrm{N}$ ratio but not litter quantity was also stable along the successional stages, litter quality could be a major factor influencing SOC in "meso". However, we cannot exclude the possibility that the stabilization of SOC in "meso" could be the effect of two opposing factors: an increase in litter $\mathrm{C}$ input with succession would tend to increase SOC, while the decreases in bulk density and soil $\mathrm{C} / \mathrm{N}$ ratio would tend to decrease SOC.

It is surprising that litter quality in "meso" remained stable along the successional gradient because shrub encroachment is accompanied by an increase in litter lignin content, which is expected to increase litter $\mathrm{C} / \mathrm{N}$ ratio (Montané et al. 2010). Along the succession from pasture to shrubland, litter $\mathrm{N}$ increased less rapidly than litter $\mathrm{C}$ in "thermo" and "supra", but increased at equal rates in "meso", indicating that differences in litter quality among bioclimates were caused by differences in the colonizing shrub species. Vegetation in "supra" evolves from herb-dominated pastures with high-quality litter to deciduous shrublands, where litter quality is moderately lowered by lignin content. In contrast, vegetation in "thermo" evolves from pastures dominated by perennial grasses to evergreen low maquis, causing a strong reduction of litter quality due to enhanced lignin content and the presence of evergreen leaf litter. In "meso", litter quality does not change significantly because the vegetation evolves from herb- and grass-dominated pastures to mainly deciduous shrublands, both of which produce litter of moderately low quality.

\section{Conclusions}

The present study showed that soil $\mathrm{C}$ and $\mathrm{N}$ storage in a semi-arid environment are affected by stage of succession and bioclimate, and that litter quality plays an important role in SOC dynamics. The differences in $\mathrm{C}$ stocks and $\mathrm{N}$ contents among bioclimates apparently reflected the contrasting effects of litter input (net primary production) and its transformation into humified organic matter (litter quality, temperature, and moisture). Successional changes in "supra" and "meso" seemed to be most influenced by litter quality, while those in "thermo" appeared to be strongly influenced by limited litter decay due to low soil moisture and high temperature.

\section{Acknowledgments}

This work was financially supported by the PRIN project "The impacts of secondary succession processes on carbon storage in soil and biomass and on biodiversity and the role of dispersal centres and vectors for recolonization processes" (National Coordinator: Riccardo Valentini). We thank Bruce Jaffee for the revision of the English version of the manuscript. We also thank the $A s$ sessorato Regionale Risorse Agricole e Alimentari - Dipartimento Interventi Infrastrutturali per l'Agricoltura - Servizio VI - Sistema Informativo Territoriale - Regione Siciliana (Palermo, Italy) for providing the unpublished pedological data. We also thank the Regional Park of Madonie for the logistic support provided.

\section{References}

Alberti G, Peressotti A, Piussi P, Zerbi G (2008). Forest ecosystem carbon accumulation during a secondary succession on Eastern Prealps (Italy). Forestry 81: 1-11. - doi: 10.1093/forestry/cpm0 26

Alberti G, Leronni V, Piazzi M, Petrella F, Cairota P, Peressotti A, Piussi P, Valentini R, Gristina L, La Mantia T, Novara A, Rühl J (2011). Impact of woody encroachment on soil organic carbon and nitrogen in abandoned agricultural lands along a rainfall gradient in Italy. Regional Environmental Change 11 (4): 917-924. - doi: 10.1007/ s10113-011-0229-6

Aneja MK, Sharma S, Fleischmann F, Stich S, Heller W, Bahnweg G, Munch JC, Schloter M (2005). Microbial colonization of beech and spruce litter - influence of decomposition site and plant litter species on the diversity of microbial community. Microbial Ecology 52: 127-135. - doi: 10.1007/s00248-006-9006-3

Bazan G, Brullo S, Raimondo FM, Schicchi R
(2010). La serie di vegetazione della Regione Sicilia. In: "La vegetazione d'Italia" (Blasi C ed). Palombi \& Partner S.r.l., Roma, Italy, pp. 429469. [in Italian]

Blake GR, Hartge KH (1986). Bulk density. In: "Methods of soil analysis ( $2^{\text {nd }}$ edn)" (Klute A ed). Part 1, vol. 9, Agronomy Monograph, American Society of Agronomy, Madison, WI, USA, pp. 363-375.

Bonet B (2004). Secondary succession of semiarid Mediterranean old-fields in south-eastern Spain: insights for conservation and restoration of degraded lands. Journal of Arid Environment 56: 213-233. - doi: 10.1016/S0140-1963(03) 00048-X

Carl T, Richter M (1989). Geoecological and morphological processes on abandoned vine-terraces in the Cinque Terre Liguria. Geoökodynamik 10: 125-158.

Castro H, Fortunel C, Freitas H (2010). Effects of land abandonment on plant litter decomposition in a Montado system: relation to litter chemistry and community functional parameters. Plant and Soil 333: 181-190. - doi: 10.1007/s11104-0100333-2

Cornwell WK, Cornelissen J, Amatangelo K, Dorrepaal E, Eviner VT, Godoy O, Hobbie SE, Hoorens B, Kurokawa $\mathrm{H}$, Pérez-Harguindeguy $\mathrm{N}$, Quested HM, Santiago LS, Wardle DA, Wright IJ, Aerts R, Allison SD, van Bodegom P, Brovkin V, Chatain A, Callaghan TV, Diaz S, Garnier E, Gurvich DE, Kazakou E, Klein JA, Read J, Reich PB, Soudzilovskaia NA, Vaieretti MV, Westoby M (2008). Plant species traits are the predominant control on litter decomposition rates within biomes worldwide. Ecology Letters 11: 1065-1071. - doi: 10.1111/j.1461-0248. 2008.01219.x

Cortez J, Garnier E, Pérez-Harguindeguy N, Debussche M, Gillon D (2007). Plant traits, litter quality and decomposition in a Mediterranean old-field succession. Plant and Soil 296: 19-34. doi: 10.1007/s11104-007-9285-6

Dai W, Huang Y (2006). Relation of soil organic matter concentration to climate and altitude in zonal soils of China. Catena 65: 87-94. - doi: 10.1016/j.catena.2005.10.006

Davis MR, Allen RB, Clinton PW (2003). Carbon storage along a stand development sequence in a New Zealand Nothofagus forest. Forest Ecology and Management 177: 313-321. - doi: 10.1016/ S0378-1127(02)00333-X

Dawson JJC, Smith P (2007). Carbon losses from soil and its consequences for land management. Science of the Total Environment 382: 165-190. - doi: 10.1016/j.scitotenv.2007.03.023

Decaëns T, Dutoit T, Alard D, Lavelle P (1998). Factors influencing soil macrofaunal comunities in post-pastoral successions of western France. Applied Soil Ecology 9: 361-367. - doi: 10.1016/ S0929-1393(98)00090-0

Drago A, Lo Bianco B, Monterosso I (2002). Atlante climatologico della Sicilia. Assessorato Agricoltura e Foreste. Servizio Informativo Agrometereologico Siciliano. Regione Siciliana. [online] URL: http://www.sias.regione.sicilia.it 
Fanelli G, Lestini M, Serafini Sauli A (2008) Floristic gradients of herbaceous vegetation and $\mathrm{P} / \mathrm{N}$ ratio in soil in a Mediterranean area. Plant Ecology 194: 231-242. - doi: 10.1007/s11258007-9287-8

FAO (2012). FAO Database. [online] URL: http://faostat.fao.org/site/377/default.aspx\#ancor Fioretto A, Papa S, Pellegrino A, Ferrigno A (2009). Microbial activities in soils of a Mediterranean ecosystem in different successional stages. Soil Biology and Biochemistry 41: 20612068. - doi: 10.1016/j.soilbio.2009.07.010

Foote RL, Grogan P (2010). Soil carbon accumulation during temperate forest succession on abandoned low productivity agricultural lands. Ecosystems 13: 795-812. - doi: 10.1007/s10021010-9355-0

Franco-Pizana JG, Fulbright TE, Gardinier DT, Tipton AR (1996). Shrub emergence and seedling growth in microenvironments created by Prosopis glandulosa. Journal of Vegetation Science 7: 257-264. - doi: 10.2307/3236326

Garcia-Pausas J, Casals P, Romanyà J (2004). Litter decomposition and faunal activity in Mediterranean forest soils: effects of $\mathrm{N}$ content and the moss layer. Soil Biology and Biochemistry 36 989-997. - doi: 10.1016/j.soilbio.2004.02.016

Gasparini P, Di Cosmo L, Morelli S, Paletto A, Tosi V, Huez B, Gregori E, Rodeghiero M, Frizzera L, Tonolli S (2008). Manuale di campagna per il rilievo degli attributi integrativi (Fase $3+$ ). Inventario Nazionale delle Foreste e dei Serbatoi Forestali di Carbonio INFC, Trento, Italy, pp. 114. [online] URL: http://mpf.entecra.it/files/manuale fase $3+\% 20$ INFC.pdf

Glenn-Lewin DC, Peet RK, Veblen TT (1992). Plant succession - theory and prediction. Population and community biology series 11 , University Press, Cambridge, UK.

Goodale CL, Davidson EA (2002). Uncertain sinks in the shrubs. Nature 418: 593-594. - doi: 10.1038/418593a

Guo LB, Gifford RM (2002). Soil carbon stocks and land use change: a meta analysis. Global Change Biology 8 (4): 345-360. - doi: 10.1046/ j.1354-1013.2002.00486.x

Hontoria C, Rodríguez-Murillo JC, Saa A (1999). Relationships between soil organic carbon and site characteristics in Peninsular Spain. Soil Science Society of America Journal 63: 614-621. doi: $10.2136 /$ sssaj 1999.03615995006300030026 $\mathrm{x}$

Incerti $\mathrm{G}$, Bonanomi $\mathrm{G}$, Giannino $\mathrm{F}$, Rutigliano F.A, Piermatteo D, Castaldi S, De Marco A, Fierro A, Fioretto A, Maggi O, Papa S, Persiani A.M, Feoli E, Virzo De Santo A, Mazzoleni S (2011). Litter decomposition in Mediterranean ecosystems: modelling the controlling role of climatic conditions and litter quality. Applied Soil Ecology 49: 148-157. - doi: 10.1016/j.apsoil. 2011.06.004

ISO 10694 (1995). Soil quality - determination of organic and total carbon after dry combustion (elementary analysis). International Organization for Standardization. Geneva, Switzerland, pp. 7. [online] URL: http://www.iso.ch
Jackson RB, Banner JL, Jobbágy EG, Pockman WT, Wall DH (2002). Ecosystem carbon loss with woody plant invasion of grasslands. Nature 418: 623-626. - doi: 10.1038/nature00910

Jangid K, Williams MA, Franzluebbers AJ, Schmidt TM, Coleman DC, Whitman WB (2011). Land-use history has a stronger impact on soil microbial community composition than aboveground vegetation and soil properties. Soil Biology and Biochemistry 43: 2184-2193. - doi: 10.1016/j.soilbio.2011.06.022

Kazakou E, Violle C, Roumet C, Pintor C, Giminez O, Garnier E (2009). Litter quality and decomposability of species from a Mediterranean succession depend on leaf traits but not on nitrogen supply. Annals of Botany 104: 1151-1161. doi: 10.1093/aob/mcp202

Knoepp JD, Coleman DC, Crossley Jr DA, Clark JS (2000). Biological indices of soil quality: an ecosystem case study of their use. Forest Ecology and Management 138: 357-368. - doi: 10.1016/ S0378-1127(00)00424-2

Knops JMH, Tilman D (2000). Dynamics of soil nitrogen and carbon accumulation for 61 years after agricultural abandonment. Ecology 81 (1): 88-98. - doi: 10.1890/0012-9658(2000)081[00 88:DOSNAC]2.0.CO;2

Koukoura Z, Mamolos AP, Kalburtji KL (2003). Decomposition of dominant plant species litter in a semi-arid grassland. Applied Soil Ecology 23: 13-23. - doi: 10.1016/S0929-1393(03)000 06-4

Kuemmerle T, Olofsson P, Chaskovsky O, Baumann M, Ostapowicz K, Woodcock CE, Houghton RA, Hostert P, Keeton WS, Radeloff VC (2011). Post-Soviet farmland abandonment, forest recovery, and carbon sequestration in western Ukraine. Global Change Biology 17(3): 1335-1349. - doi: 10.1111/j.1365-2486.2010. 02333.x

La Mantia T, Oddo G, Rühl J, Furnari G, Scalenghe R (2007). Variation of soil carbon stocks during the renaturation of old fields: the case study of the Pantelleria Island, Italy. Forest@ 4 (1): 102-109. [in Italian] - doi: 10.3832/efor043 3-0040102

Lal R (2004a). Soil carbon sequestration to mitigate climate change. Geoderma 123: 1-22. - doi: 10.1016/j.geoderma.2004.01.032

Lal R (2004b). Soil carbon sequestration impacts on global climate change and food security. Science 304: 1623-1627. - doi: 10.1126/science. 109 7396

Liao JD, Boutton TW (2008). Soil microbial biomass response to woody plant invasion of grassland. Soil Biology and Biochemistry 40: 12071216. - doi: 10.1016/j.soilbio.2007.12.018

Luken JO (1990). Directing ecological succession. The University Press, Cambridge, UK.

Marzaioli R, D'Ascoli R, De Pascale RA, Rutigliano FA (2010). Soil quality in a Mediterranean area of Southern Italy as related to different land use types. Applied Soil Ecology 44: 205-212. - doi: 10.1016/j.apsoil.2009.12.007

Mayer PM (2008). Ecosystem and decomposer effects on litter dynamics along an old field to old- growth forest successional gradient. Acta Oecologica 33: 222-230. - doi: 10.1016/j.actao.2007. 11.001

Montané F, Rovira P, Casals P (2007). Shrub encroachment into mesic mountain grasslands in the Iberian Peninsula: effects of plant quality and temperature on soil $\mathrm{C}$ and $\mathrm{N}$ stocks. Global Biogeochemical Cycles 21: GB4016. - doi: 10.1029/2006GB002853

Montané $\mathrm{F}$, Romanyà $\mathrm{J}$, Rovira $\mathrm{P}$, Casals $\mathrm{P}$ (2010). Aboveground litter quality changes may drive soil organic carbon increase after shrub encroachment into mountain grasslands. Plant and Soil 337: 151-165. - doi: 10.1007/s11104-0100512-1

Papa S, Pellegrino A, Fioretto A (2008). Microbial activity and quality changes during decomposition of Quercus ilex leaf litter in three Mediterranean woods. Applied Soil Ecology 40: 401410. - doi: 10.1016/j.apsoil.2008.06.013

Paul KI, Polglase PJ, Nyakuengama JG, Khanna PK (2002). Change in soil carbon following afforestation. Forest Ecology and Management 168: 241-257. - doi: 10.1016/S0378-1127(01) 00740-X

Pinzari F, Trinchera A, Benedetti A, Sequi $\mathrm{P}$ (1999). Use of biochemical indices in the mediterranean environment: comparison among soils under different forest vegetation. Journal of Microbiological Methods 36: 21-28. - doi: 10.1016/ S0167-7012(99)00007-X

Poll C, Marhan S, Ingwersen J, Kandeler E (2008). Dynamics of litter carbon turnover and microbial abundance in a rye detritusphere. Soil Biology and Biochemistry 40: 1306-1321. - doi: 10.1016/j.soilbio.2007.04.002

Prévosto B, Dambrine E, Coquillard P, Robert A (2006). Broom (Cytisus scoparius) colonization after grazing abandonment in the French Massif Central: impact on vegetation composition and resource availability. Acta Oecologica 30: 258268. - doi: 10.1016/j.actao.2006.05.001

Pérez-Harguindeguy N, Díaz S, Cornelissen J, Vendramini F, Cabido M, Castellanos A (2000). Chemistry and toughness predict leaf litter decomposition rates over a wide spectrum of functional types and taxa in central Argentina. Plant and Soil 218: 21-30. - doi: 10.1023/A:101498 1715532

Rivas-Martínez S (2004). Global bioclimatics (Clasificación Bioclimática de la Tierra). [online] URL: http://www.globalbioclimatics.org Rodríguez Pleguezuelo CR, Durán Zuazo VH, Muriel Fernández JL, Martín Peinado, FJ, Franco Tarifa D (2009). Litter decomposition and nitrogen release in a sloping Mediterranean subtropical agroecosystem on the coast of Granada (SE, Spain). Effects of floristic and topographic alteration on the slope. Agriculture, Ecosystems and Environment 134: 79-88. - doi: 10.1016/j.agee. 2009.05.019

Romanyà J, Casals P, Vallejo VR (2001). Shortterm effects of fire on soil nitrogen availability in Mediterranean grasslands and shrublands growing in old fields. Forest Ecology and Management 147: 39-53. - doi: 10.1016/S0378-1127(00) 
00433-3

Rutigliano FA, Ascoli RD, Virzo de Santo A (2004). Soil microbial metabolism and nutrient status in a Mediterranean area as affected by plant cover. Soil Biology and Biochemistry 36: 1719-1729. - doi: 10.1016/j.soilbio.2004.04.029 Sardans J, Peñuelas J, Estiarte M (2008). Changes in soil enzymes related to $\mathrm{C}$ and $\mathrm{N}$ cycle and in soil $\mathrm{C}$ and $\mathrm{N}$ content under prolonged warming and drought in a Mediterranean shrubland. Applied Soil Ecology 39: 223-235. - doi: 10.1016/ j.apsoil.2007.12.011

Vuichard N, Ciais P, Belelli L, Smith P, Valentini $R$ (2008). Carbon sequestration due to the abandonment of agriculture in the former USSR since 1990. Global Biogeochemical Cycles 22:
GB4018. - doi: 10.1029/2008GB003212.

West DC, Shugart HH, Botkin DB (1981). Forest Succession - concepts and application. Springer. New York, USA.

WRB (1998). World reference base for soil resources. World soil resources report 84, ISSS, ISRIC and FAO, Rome, Italy. 